\title{
The Effectiveness of Think Pair Share Learning Model with a Problem Based Learning Approach Based on Students' Self-efficacy
}

\author{
Ahmad Mukhibin ${ }^{1 *}$, Nur Ichsan ${ }^{2}$ \\ ${ }^{1}$ Program Studi Tadris Matematika IAIN Salatiga, Indonesia. \\ a.mukhibin1@gmail.com
}

\begin{abstract}
Abstrak
Tujuan penelitian ini adalah untuk mengetahui apakah model pembelajaran think pair share dengan pendekatan problem based learning efektif ditinjau dari self-efficacy siswa. Penelitian ini merupakan penelitian kuantitatif yang berupa eksperimen semu dengan menggunakan desain penelitian pretest-posttest control group design. Sampel penelitian adalah siswa kelas X MIPA MAN Salatiga tahun pelajaran 2018/2019, sampel ditentukan dengan menggunakan teknik Cluster Random Sampling. Pengambilan data dilakukan dengan menggunakan angket self-efficacy yang terdiri dari 20 pernyataan. Adapun hasil penelitian menunjukkan bahwa: (1) hasil uji independent sample t test ratarata self-efficacy siswa diperoleh nilai sebesar 0,035 , (2) rata-rata skor $N$-Gain self-efficacy siswa yang mendapat pembelajaran dengan menggunakan model think pair share dengan pendekatan problem based learning sebesar 0,36 sedangkan rata-rata skor $N$-Gain self-efficacy siswa yang mendapat pembelajaran konvensional hanya sebesar 0,23. Dengan demikian dapat disimpulkan bahwa model pembelajaran think pair share dengan pendekatan problem based learning efektif ditinjau dari selfefficacy siswa kelas X MIPA MAN Salatiga tahun pelajaran 2018/2019.
\end{abstract}

Kata Kunci: Self-efficacy, Problem based learning, Think pair share.

\begin{abstract}
The purpose of this study is to determine whether the think pair share learning model with a problem based learning approach is effective based on students' self-efficacy. This research is a quantitative research in the form of quasi-experimental research using a pretest-posttest control group design. The sample of the study was the students of X MIPA class of MAN Salatiga in the academic year 2018/2019, the sample was determined using the Cluster Random Sampling technique. Data was collected using a self-efficacy questionnaire consisting of 20 statements. The results of the study show that: (1) the results of the independent sample t test mean students' self-efficacy obtained a value of 0.035 , (2) the average $N$-Gain score of self-efficacy of students who learned by using the think pair share model with a problem based learning approach of 0.36 while the average $N$-Gain score of selfefficacy of students who get conventional learning is only 0.23. Thus it can be concluded that the think pair share learning model with a problem based learning approach is effective based on the selfefficacy of X MIPA class of MAN Salatiga students in the academic year 2018/2019.
\end{abstract}

Keywords: Self-efficacy, Problem based learning, Think pair share. 


\title{
Jurnal Hipotenusa, 1 (1), Desember 2019
}

\author{
Ahmad Mukhibin, Nur Ichsan
}

\section{PENDAHULUAN}

Pesatnya perkembangan kemajuan zaman diperlukan pula sumber daya manusia yang kompeten dan berkualitas, yaitu sumber daya manusia yang menguasai berbagai macam keterampilan, baik keterampilan kognitif, afektif, maupun psikomotorik. Berbagai macam upaya telah dilakukan untuk memenuhi kebutuhan tersebut, salah satunya melalui pendidikan. Dalam dunia pendidikan, Pemerintah telah berupaya maksimal untuk menghasilkan sumber daya manusia yang berkualitas dengan menerapkan kurikulum 2013. Kurikulum 2013 memberi siswa waktu yang lebih leluasa untuk mengembangkan berbagai macam sikap, pengetahuan, serta keterampilan yang dimiliki. Selain itu, pembelajaran kurikulum 2013 juga mengharuskan siswa untuk memiliki keyakinan diri terhadap kemampuan yang dimiliki agar siswa mampu mengikuti serangkaian proses pembelajaran dengan baik dan mampu mencapai hasil belajar yang optimal.

Keyakinan diri terhadap kemampuan serta potensi yang dimiliki disebut dengan selfefficacy (Sutanto, 2018:277). Bandura (1997:2) menjelaskan self-efficacy, "perceived selfefficacy refers to beliefs in one's capabilities to organize and execute the courses of action required to manage prospective situation. Efficacy beliefs influence how people think, feel, motivate themselves, and act". Sementara Ghufron \& Rini (2010:77) menjelaskan selfefficacy secara umum adalah keyakinan diri individu terhadap kemampuan-kemampuannya dalam mengatasi berbagai situasi. Self-efficacy tidak berkaitan dengan kecakapan yang dimiliki, tetapi berkaitan dengan keyakinan individu mengenai hal yang dapat dilakukan dengan kecakapan yang ia miliki. Jadi self-efficacy itu merupakan suatu kepercayaan diri yang dimiliki oleh individu untuk dapat menyelesaikan berbagai permasalahan yang dihadapi.

Self-efficacy sangat berperan penting di kehidupan sehari-hari dalam upaya menghadapi dan menyelesaikan suatu permasalahan yang terjadi (Alifia, 2018:51). Individu akan mampu menggunakan potensi yang dimilikinya apabila memiliki self-efficacy yang mendukung (Rustika, 2012:18). Individu dengan selfefficacy yang rendah cenderung akan mempersepsikan sesuatu lebih sulit daripada kenyataan yang terjadi serta lebih memilih untuk menyerah sebelum berusaha maksimal menghadapi dan memecahkan permasalahan. Akan tetapi, individu dengan self-efficacy yang tinggi akan mempersepsikan sesuatu lebih mudah daripada apa yang terjadi dan senantiasa berusaha lebih keras dalam mengatasi permasalahan yang terjadi.

Self-efficacy dapat memainkan peran penting dalam proses pembelajaran matematika karena matematika tergolong sebagai mata pelajaran yang sulit di sekolah, akibatnya persepsi siswa terhadap mata pelajaran matematika di sekolah akan sangat menentukan hasil belajar dan masa depan siswa. Sulitnya matematika tentu tidak terlepas dari pengertian matematika itu sendiri, Noer (2017:4) menyatakan bahwa matematika merupakan ilmu terstruktur yang terorganisasikan karena konsepkonsep matematika tersusun secara hierarkis, logis, dan sistematis mulai dari konsep yang sederhana hingga pada konsep yang paling kompleks. Sehingga dalam memahami matematika diperlukan pemahaman yang lebih mendalam. Shadiq (2014:1) mengatakan bahwa memahami matematika tidak semudah seperti apa yang dibayangkan alasannya karena definisi dan tujuan pembelajaran matematika akan selalu berubah sesuai dengan perkembangan zaman, sehingga seiring bertambahnya tahun, maka matematika juga akan semakin berkembang.

Siswa dengan tingkat self-efficacy tinggi akan berusaha bertahan dalam menghadapi tugas-tugas matematika yang sulit, berusaha membangun komitmen yang kuat dalam menyelesaikan tugas serta berupaya untuk meningkatkan usaha dalam menghadapi kesulitan menyelesaikan tugas matematika di sekolah sehingga siswa dengan tingkat selfefficacy yang tinggi cenderung akan mencapai hasil belajar matematika yang maksimal. Sebaliknya, siswa dengan tingkat self-efficacy yang rendah cenderung lebih memilih untuk menghidari tugas matematika yang diberikan karena merasa terancam dengan adanya tugas tersebut, konsekuensinya adalah melemahkan komitmen siswa dalam upaya menyelesaikan tugas matematika sehingga siswa cenderung lebih mudah menyerah dan mudah stress. Hal ini mengakibatkan semakin tinggi self-efficacy siswa maka semakin tinggi pula motivasi berprestasinya. Sebaliknya, semakin rendah selfefficacy siswa maka motivasi berprestasi siswa juga semakin rendah (Yuliantika, dkk, 2017:57).

Konseptualisasi self-efficacy dalam pembelajaran matematika disebut dengan selfefficacy matematik. Yates mendefinisikan self- 


\title{
Jurnal Hipotenusa, 1 (1), Desember 2019
}

\author{
Ahmad Mukhibin, Nur Ichsan
}

efficacy matematik sebagai sebuah konsep diri terkait kepercayaan seseorang pada kemampuannya untuk melakukan atau menyelesaikan suatu tugas atau permasalahan dalam matematika (Pardimin, 2018:32). Senada dengan hal tersebut, Jumroh, dkk (2018:31) mendefinisikan self efficacy dalam mata pelajaran matematika adalah kemampuan siswa untuk mempresentasikan dan menyelesaikan permasalahan matematika, cara belajar memahami konsep dan cara menyelesaikan tugas, serta kemampuan berkomunikasi matematika dengan teman sebaya maupun dengan guru.

Mengingat pentingnya self-efficacy dalam pembelajaran, maka diperlukan suatu model pembelajaran dengan pendekatan tertentu yang bisa digunakan sebagai variasi penggunaan model pembelajaran. Salah satu alternatif yang bisa digunakan untuk mengatasi ataupun meningkatkan self-efficacy siswa adalah melalui proses pembelajaran yang berbasis pada masalah. Pendekatan problem based learning merupakan pendekatan pembelajaran yang berdasarkan pada masalah dan masalah tersebut belum diketahui jawabannya sehingga harus diselesaikan dengan proses diskusi dengan teman lainnya atau dengan kelompok diskusi. Untuk menunjang kegiatan tersebut maka juga dibutuhkan model pembelajaran yang dapat mendukung kegiatan tersebut. Salah satu model yang bisa diterapkan adalah model pembelajaran Think Pair Share (TPS). TPS dinilai cocok untuk diterapkan pada pendekatan PBL karena pembelajaran menggunakan model TPS terdapat langkah di mana siswa bersama-sama menyelesaikan masalah, mendiskusikan masalah secara berkelompok, serta membagikan hasil diskusinya kepada kelompok lain sehingga model pembelajaran TPS dinilai efektif untuk menumbuhkan dan meningkatkan self-efficacy siswa.

Berdasarkan uraian permasalahan di atas, maka peneliti tertarik untuk melakukan penelitian dengan judul "Keefektifan Model Pembelajaran Think Pair Share dengan Pendekatan Problem Based Learning Ditinjau dari Self-efficacy Siswa". Tujuan penelitian ini adalah untuk mengetahui keefektifan model pembelajaran think pair share dengan pendekatan problem based learning ditinjau dari self-efficacy siswa.

Hipotesis yang diajukan dalam penelitian ini adalah (1) rata-rata self-efficacy siswa yang mendapat pembelajaran dengan menggunakan model pembelajaran think pair share dengan pendekatan problem based learning lebih dari rata-rata self-efficacy siswa yang mendapat pembelajaran dengan menggunakan model konvensional, (2) rata-rata skor $N$-Gain selfefficacy siswa yang mendapat pembelajaran dengan menggunakan model pembelajaran think pair share dengan pendekatan problem based learning lebih dari rata-rata skor $\mathrm{N}$-Gain selfefficacy siswa yang mendapat pembelajaran dengan menggunakan model konvensional.

\section{METODE}

Penelitian ini merupakan penelitian kuantitatif yang berupa eksperimen semu yang didesain dengan menggunakan pretest-posttest control groups desaign. Penelitian dilaksanakan pada bulan Maret 2019 di Madrasah Aliyah Negeri (MAN) Salatiga tahun pelajaran 2018/2019 dengan sampel penelitian adalah siswa kelas X MIPA 2 dan X MIPA 3. Sampel diambil dengan menggunakan teknik Cluster Random Sampling. Sedangkan teknik pengambilan data berupa angket self-efficacy yang diberikan kepada siswa sebelum dan sesudah pembelajaran dengan metode yang berbeda. Angket penelitian sebelumnya sudah divalidasi oleh dua orang ahli (experts judgement) dan juga telah diujicobakan kepada 29 siswa.

Model pembelajaran think pair share dengan pendekatan problem based learning yang dimaksud dalam penelitian ini adalah siswa diberi waktu untuk menyelesaikan soal secara individu, kemudian berkelompok dan bertukar pendapat, hingga mempresentasikan di depan kelas. Tujuan kegiatan pembelajaran tersebut adalah untuk melatih self-efficacy siswa sehingga tidak dinilai benar atau salah dalam menyelesaikan persoalan yang diberikan. Selfefficacy yang dimaksud meliputi 3 dimensi, yaitu: magnitude, strength, dan generality.

\section{HASIL DAN PEMBAHASAN}

Data hasil angket self-efficacy siswa dari kelas yang mendapat pembelajaran dengan menggunakan model think pair share dengan pendekatan problem based learning maupun kelas yang mendapat pembelajaran dengan menggunakan model konvensional disajikan secara deskriptif berdasarkan nilai angket sebelum dan sesudah dilakukan pembelajaran. 
Adapun data hasil angket self-efficacy siswa kedua kelas disajikan pada Tabel 1.

Tabel 1. Data Hasil Angket

\begin{tabular}{lcccc}
\hline Hasil & \multicolumn{2}{c}{ Eksperimen } & \multicolumn{2}{c}{ Kontrol } \\
\cline { 2 - 5 } & Sebelum & Sesudah & Sebelum & Sesudah \\
Min. & 38 & 49 & 39 & 48 \\
Max. & 62 & 78 & 63 & 69 \\
Mean & 52,11 & 62,08 & 52,19 & 59,25 \\
\hline
\end{tabular}

Berdasarkan Tabel 1 pada hasil angket sebelum pembelajaran pada kelas eksperimen diperoleh nilai minimum sebesar 38 , nilai maksimum 62 dan rata-rata sebesar 52,11. Sementara hasil angket sebelum pembelajaran pada kelas kontrol diperoleh nilai minimum sebesar 39, nilai maksimum sebesar 63 , dan rata-rata sebesar 52,19. Hal tersebut menunjukkan bahwa kedua kelas berangkat dari self-efficacy yang sama.

Sedangkan pada hasil agket kelas eksperimen sesudah pembelajaran diperoleh nilai minimum sebesar 49, nilai maksimum sebesar 78, dan nilai rata-rata sebesar 62,08. Sementara untuk hasil angket pada kelas kontrol sesudah pembelajaran diperoleh nilai minimum sebesar 48, nilai maksimum sebesar 69 , dan nilai rata-rata sebesar 59,25. Hal tersebut menunjukkan bahwa self-efficacy siswa yang mendapat pembelajaran dengan menggunakan model think pair share dengan pendekatan problem based learning lebih dari self-efficacy siswa yang mendapat pembelajaran dengan menggunakan model pembelajaran konvensial.

Berdasarkan hasil uji prasyarat yang telah dilakukan, data hasil angket self-efficacy siswa berdistribusi normal dan juga homogen sehingga dapat dilakukan pengujian hipotesis dengan menggunakan independent sample t test untuk mengetahui perbedaan rata-rata self-efficacy antara siswa kelas eksperimen dan siswa kelas kontrol. Adapun hasil dari uji independent sample t test disajikan pada Tabel 2.

Tabel 2. Hasil Uji Independent Sample t Test

\begin{tabular}{lccccc}
\hline \multirow{2}{*}{ Hasil } & \multicolumn{2}{c}{ Uji F } & \multicolumn{3}{c}{ Uji t } \\
\cline { 2 - 6 } & $\mathrm{F}$ & Sig. & df & T & Sig. \\
\hline $\begin{array}{l}\text { Equal } \\
\text { variances } \\
\text { assumed }\end{array}$ & & & 70 & 0,631 & 0,035 \\
$\begin{array}{l}\text { Equal } \\
\text { variances } \\
\text { not } \\
\text { assumed }\end{array}$ & 1,563 & 0,215 & & & \\
\hline
\end{tabular}

Berdasarkan Tabel 2 diperoleh nilai signifikansi $\mathrm{F}$ sebesar $0,215>0,05$ sehingga varian self-eficacy antara siswa kelas eksperimen dan kelas kontrol adalah sama. Dengan demikian pada uji independent sample $t$ test menggunakan asumsi equal variances asummed, dari Tabel 2 maka diperoleh nilai signifikansi pada uji t sebesar $0,035<0,05$ sehingga dapat disimpulkan bahwa $\mathrm{H}_{0}$ ditolak dan $\mathrm{H}_{1}$ diterima yang berarti bahwa terdapat perbedaan self-efficacy antara siswa yang mendapat pembelajaran dengan menggunakan model think pair share dengan pendekatan problem based learning dengan self-efficacy siswa yang mendapat pembelajaran dengan menggunakan model konvensional.

Selain itu hasil dari perhitungan skor $N$ Gain self-efficacy siswa sebagaimana disajikan pada Tabel 3 juga menunjukkan bahwa selfefficacy siswa yang mendapat pembelajaran dengan menggunakan model think pair share dengan pendekatan problem based learning sebesar 0,36 lebih dari self-efficacy siswa yang mendapat pembelajaran dengan menggunakan model konvensional yang hanya sebesar 0,23.

Tabel 4. Data Skor N-Gain

\begin{tabular}{ccc}
\hline Indeks skor & $\begin{array}{c}\text { Jumlah siswa } \\
\text { Kelas Eksperimen }\end{array}$ & $\begin{array}{c}\text { Jumlah siswa } \\
\text { Kelas Kontrol }\end{array}$ \\
\hline$g>0,7$ & 1 & 0 \\
$0,3<g \leq 0,7$ & 17 & 10 \\
$g \leq 0,3$ & 18 & 26 \\
Rata-rata & 0,36 & 0,23 \\
\hline
\end{tabular}

Berdasarkan Tabel 3 siswa kelas eksperimen yang mengalami peningkatan kategori tinggi sebanyak 1 siswa, sedang sebanyak 17 siswa, dan 18 siswa lainnya mengalami peningkatan self-efficacy kategori rendah. Sementara pada kelas kontrol, 26 siswa mengalami peningkatan rendah, 10 siswa mengalami peningkatan sedang, dan tidak ada satupun siswa yang mengalami peningkatan tinggi. Dengan demikian dapat disimpulkan bahwa peningkatan rata-rata self-efficacy siswa kelas eksperimen lebih baik daripada peningkatan self-efficacy siswa kelas kontrol.

Berdasarkan hasil penelitian di atas maka diperoleh informasi bahwa hasil uji independent sample $t$ test pada angket self-efficacy siswa kedua kelas diperoleh nilai signifikansi (2tailed) sebesar 0,035. Hal ini menunjukkan bahwa hipotesis pertama yang menyatakan 


\section{Jurnal Hipotenusa, 1 (1), Desember 2019}

Ahmad Mukhibin, Nur Ichsan

bahwa terdapat perbedaan self-efficacy antara siswa yang mendapat pembelajaran dengan menggunakan model think pair share dengan pendekatan problem based learning dan siswa yang mendapat pembelajaran dengan menggunakan model konvensional juga telah terpenuhi.

Selain itu, hasil perhitungan skor $N$-Gain juga diperoleh informasi bahwa skor rata-rata peningkatan self-efficacy siswa yang mendapat pembelajaran dengan menggunakan model think pair share dengan pendekatan problem based learning sebesar 0,36 lebih dari skor rata-rata peningkatan self-efficacy siswa yang mendapat pembelajaran dengan menggunakan model konvensional. Sehingga hipotesis kedua yang menyatakan bahwa rata-rata peningkatan selfefficacy siswa yang mendapat pembelajaran dengan menggunakan model think pair share dengan pendekatan problem based learning lebih dari rata-rata peningkatan self-efficacy siswa yang mendapat pembelajaran dengan menggunakan model konvensional juga telah terpenuhi.

Berdasarkan hasil uji hipotesis yang telah dipaparkan maka dapat diambil kesimpulan bahwa model pembelajaran think pair share dengan pendekatan problem based learning efektif ditinjau dari self-efficacy siswa. Keefektifan penerapan model think pair share dengan pendekatan problem based learning dapat terjadi karena pada model pembelajaran ini menampilkan pembelajaran yang lebih menarik dan menuntut siswa untuk lebih aktif dalam mengemukakan pendapat kepada pasangan diskusinya dan juga mempresentasikan hasil diskusi di depan kelas. Lebih lanjut, dalam proses penyelesaian permasalahan yang diberikan, siswa dituntut untuk tetap bertahan dan berusaha mencari penyelesaian masalah yang dihadapi. Hal ini sangat memungkinan bahwa siswa kelas yang mendapat pembelajaran model think pair share dengan pendekatan problem based learning untuk melatih tingkat kepercayaan diri siswa.

Selain itu, selama proses pembelajaran dengan menggunakan model think pair share dengan pendekatan problem based learning baik guru maupun siswa telah melaksanakan sintaks pembelajaran dengan cukup baik sehingga proses pembelajaran dapat berlangsung dengan maksimal. Hal tersebut berimplikasi langsung terhadap self-efficacy siswa sehingga model pembelajaran think pair share dengan pendekatan problem based learning dinilai efektif ditinjau dari self-efficacy.

Hasil penelitian ini sejalan dengan penelitian yang telah dilakukan oleh Hardiyanto, dkk (2018) yang menyebutkan bahwa pembelajaran dengan menggunakan pedekatan problem based learning setting think pair share efekti untuk meningkatkan self-efficacy siswa. selain itu, penelitian yang dilakukan oleh Rahayu, dkk (2017) juga menunjukkan bahwa model pembelajaran kooperatif tipe think pair share berpengaruh terhadap self-efficacy siswa.

\section{SIMPULAN}

Berdasarkan hasil penelitian dan pembahasan yang telah diuraikan di atas, maka diperoleh informasi bahwa: (1) rata-rata selfefficacy siswa yang mendapat pembelajaran dengan menggunakan model think pair share dengan pendekatan problem based learning lebih dari rata-rata self-efficacy siswa yang mendapat pembelajaran dengan menggunakan model konvensional, (2) rata-rata peningkatan self-efficaccy siswa yang mendapat pembelajaran dengan menggunakan model think pair share dengan pendekatan problem based learning juga lebih dari rata-rata peningkatan self-efficacy siswa yang mendapat pembelajaran dengan menggunakan model konvensional. Dengan demikian dapat disimpulkan bahwa model pembelajaran think pair share dengan pendekatan problem based learning efektif ditinjau dari self-efficacy siswa.

\section{DAFTAR PUSTAKA}

Alifia, Nugrahaning Nisa, \& Intan Aulia Rakhmawati. (2018). Kajian Kemampuan Self-Efficacy Matematis Siswa Dalam Pemecahan Masalah Matematika. Jurnal Elektronik Pembelajaran Matematika, 5(1), 44-54.

Bandura, Albert. (1997). Self-efficacy The Exercise of Control. New York: W. H. Freeman.

Ghufron, M. Nur., \& Rini Risnawati S. (2010). Teori-teori Psikologi. Yogjakarta: ArRuzz Media.

Hardiyanto, Wahyu \& Rusgianto Heri Santoso. 2018. Efektivitas PBL setting TTW dan TPS Ditinjau Dari Prestasi Belajar, Berfikir Kritis, dan Self-Efficacy Siswa. Jurnal Riset Pendidikan Matematika, 5(1), 116-126. 


\section{Jurnal Hipotenusa, 1 (1), Desember 2019}

Ahmad Mukhibin, Nur Ichsan

Jumroh., dkk. (2018). Self-Efficacy Siswa Dalam Pembelajaran Matematika Dengan Strategi Inquiry Based Learning di Kelas VII SMP Palembang. Jurnal Pendidikan Matematika RAFA, 4(1), 29-42.

Noer, Sri Hastuti. (2017). Strategi Pembelajaran Matematika. Yogyakarta: Matematika.

Pardimin. (2018). Self-Efficacy Matematika dan Self-Efficacy Mengajar Matematika Guru Matematika. Jurnal Ilmu Pendidikan, 24(1), 29-37.

Rahayu, T.R., Huda, M., \& Shodikin, Ali. 2017. Pengaruh Model Pembelajaran Kooperatif Tipe TPS dengan Alat Peraga Rubbik Terhadap Self-Efficacy Siswa Pada Materi Kubus dan Balok. INSPIRAMATIKA: Jurnal Inovasi
Pendidikan dan Pembelajaran Matematika, 3(2), 117-123.

Rustika, I Made. (2012). Efikasi Diri: Tinjauan Teori Albert Bandura. Buletin Psikologi Fakultas Psikologi Universitas Gadjah Mada, 20(1-2), 18-25.

Shadiq, Fadjar. 2014. Pembelajaran Matematika; Cara Meningkatkan Kemampuan Berfikir Kritis. Yogyakarta: Graha Ilmu.

Sutanto, Ahmad. (2018). Bimbingan dan Konseling di Sekolah. Jakarta: Prenadamedia Group.

Yuliantika, Dina. Sri W Rahmawati, \& Sukarti Retno Palupi. (2017). Self-Efficacy dan Motivasi Berprestasi Siswa SMA Negeri 7 Purworejo. Jurnal Psiko Utama, 5(2), 51-59. 